\title{
HET INSOS- EN HET K'BOR-FEEST OP BIAK EN SOEPIORL.
}

DOOR

Fr. Јон. JENS, Zendeling-Leeraar.

Biak of Wiak (op oude zeekaarten leest men Wiak) en Soepiori zijn de beide eilanden, die algemeen bekend staan als de Schouten-eilanden. De bewoners zijn Papoea's, die tot de kroesharige stammen behooren. Opmerkelijk is echter, dat men op deze eilanden ook veel personen aantreft met sluikhaar.

Biak is het oostelijkste eiland, Soepiori het westelijkste en beide ressorteeren onder den Assistent-Resident van NoordNieuw-Guinea te Menukwari, met een eigen Gezaghebber, wiens standplaats is Bosnik, aan de zuidkust van Biak. Op dezelfde plaats is ook gestationneerd een afdeeling gewapende politie.

Voor ik er toe overga beide bovengenoemde feesten te beschrijven, zet ik voorop dat ik alleen spreek over de Schouteneilanden. Het. « inso s-feest» op deze eilanden verschilt namelijk van dat in de Dorehbaai, alwaar het waarschijnlijk ingevoerd is en daardoor veel van zijn oorspronkelijken vorm heeft ingeboet.

Waar de verschilpunten ver uiteenloopen zal ik dit even nader aanduiden.

Het woord "insos» bestaat uit de twee deelen «in» en "sos». «In» is de vrouwelijke vorm (in, bin, ina), tegenover "man» de mannelijke. "In» vindt men meestal in samenstellingen zooals insar - oude vrouw; ingubor ${ }^{1}$ - jonge maagd.

Dit. is ook het geval met "man», bijv.: manseren (Manseren Allah - de Heere God) mangundi-de man zelf (zie de legende van Manseren Mangundi-de Heer hij zelf).

"Sos» is kleur. Dit is een specifiek Biaksch woord, dat men niet in de Dorehbaai kent, echter wel op het eiland Roon.

1 De $u$ in dit woord en in de volgende noefoorsche woorden wordt uitgesproken als oe. 
De nadere beteekenis van den term insos zal straks blijken. Thans zal ik eerst het feest gaan beschrijven, waardoor een meisje tot insos gemaakt wordt.

Op Biak en Soepiori wordt elk meisje tot insos gemaakt, in de Dorehbaai alleen de oudste dochter, en slechts dan wanneer haar eersteling geboren is.

Op de Schouten-eilanden kan een meisje niet huwen, tenzij zij eerst in sos wordt. De leeftijd, die een meisje moet bereikt hebben om tot insos gemaakt te kunnen worden, is zeer verschillend. Deze loopt van 5 à 6 , tot 12,13 of 15 jaar.

Zulk een meisje wordt opgesloten in een kamertje van het huis harer ouders.

Een ieder die weet hoe een papoesch huis er uit ziet, begrijpt dat het in zulk een kamertje heel donker kan zijn. Immers zulk een huis bestaat uit een lange gang (die haar licht ontvangt van de beide uiteinden) en aan weerszijde van die gang bevinden zich de kamertjes, met als eenige uitgang een deur, die in die gang uitkomt. De andere zijde van het kamertje tegenover de deur wordt gevormd door het dak dat zeer schuin afloopt.

Het kamertje wordt voor deze gelegenheid afgesloten met een mat (op sommige plaatsen bijv. Sburia wordt een kamertje gemaakt van enkel matten) en vóór die mat, dus buiten het kamertje, zit een oude vrouw die de rol vervult van bewaakster. Want de tot insos te maken jonge maagd mag tijdens een maand zich niet buiten vertoonen. Wanneer de ouders rijk zijn, duurt de opsluiting 2,3 of 4 maanden.

Voor zij echter in het kamertje treedt, worden door het "dissen wark» de geesten gunstig gestemd. (Dissen wark= zingende beletten; dus zingende wordt den geesten verzocht, geen beletselen in den weg te leggen). Deze zelfde plechtigheid heeft plaats, wanneer zij weer in het dagelijksch leven terugtreedt.

Al den tijd, dien de jonge maagd opgesloten zit, moet zij de knieën opgetrokken houden. 's Avonds en 's nachts is zij zoo vrij te liggen of te zitten zooals zij wenscht. Wanneer zij namelijk des daags een der beenen strekt, is het mogelijk, dat de geesten der voorouders zóó verbolgen zijn, dat òf de vader ò de moeder ò een harer familieleden deze vrijheid met den dood of hevige ziekten moet betalen. Het voedsel wordt haar door de oudere vrouw door de geïmproviseerde deur heen 
aangereikt. $\mathrm{Zij}$ mag het zelf tot zich nemen. Ook hier vinden wij een verschil met de Dorehbaai, waar het voedsel de vrouw in den mond gestoken wordt, door een gat, gemaakt in een der wanden van het kamertje.

De eerste 5 of 6 nachten mogen de jongere broertjes of zusjes haar gezelschap houden, die echter de volgende nachten plaats maken voor den aanstaanden echtgenoot. Op andere plaatsen, zooals ook op het bovengenoemde Sburia, wordt niemand toegelaten bij haar in het kamertje te slapen, ook niet de aanstaande echtgenoot. Bekend mag verondersteld worden dat de papoesche kinderen reeds op zeer jeugdigen leeftijd verloofd, of juister verkocht worden voor een zeer hoogen prijs.

De man koopt de vergunning om in het huis zijner schoonouders te komen, zoo hij arm is, met een hakmes; wanneer hij rijk is, met stukken blauw katoen, borden en dergelijke zaken. Hij betaalt deze schatting in eens, en heeft dan toegang voor al de nachten, gedurende welke de vrouw zit opgesloten: en natuurlijk ook daarna, want na het feest is het huwelijk een voldongen feit; of liever dan neemt de man zijn koopwaar, in dit geval het meisje, in bezit.

Op mijn vraag aan mijn zegslieden: «Waarom hij deze vergunning moet betalen», antwoordde men mij, dat hij dit deed om niet beschaamd gemaakt te worden door de familie van zijn vrouw. Betaalt hij deze schatting niet, dan zou hij iemand zijn, die niet weet de beleefdheidsvormen in acht te nemen.

Echter is er ook een andere meer afdoende reden.

Op de Schouten-eilanden toch heerscht het matriarchaat; of liever men vindt er een overgang van het matriarchaat naar het patriarchaat; zoo zal bijv. een man niet iets verkoopen zonder eerst de vergunning van zijn vrouw verkregen te hebben. (Natuurlijk zijn er wel Papoea's die deze vergunning niet vragen, doch zulke ontduikingen vindt men meer).

De man betaalt dus het betreden van het huis zijner schoonouders; hij blijft daar ook wonen tot zijn eerste kind den leeftijd heeft bereikt van \pm 10 jaar, waarna hij met zijn vrouw en kind naar zijn eigen familie terugkeert.

Tijdens de opsluiting komt een vrouw, handig in het tatoueeren, het meisje de noodige tatouages bezorgen. Dit tatoueeren heet in het noefoorsch pa.

Op haar rug wordt meestal een mannenbeeld getatoueerd, 
op het voorhoofd een prauw, soms een mannenfiguur, op de bovenarmen wederom hetzelfde, ook wel afgewisseld met een vogelfiguur. De afbeeldingen zijn echter zeer moeilijk te onderkennen.

Het tatoueeren geschiedt door middel van een vischgraat. In dezen ook voor den Papoea vooruitgaanden tijd, wordt meestal een naald of speld gebruikt.

De wonden der kleine prikjes die gemaakt worden, worden ingesmeerd met een mengsel van klapperolie en roet, het zwartsel dat zich aan potten en pannen bevindt. De vischgraat waarmede dit tatoueeren geschiedt, is afkomstig van de in daf, een vischsoort die veel overeenkomst vertoont met onzen voorn.

$\mathrm{Bij}$ haar uittreden wordt het meisje geheel versierd met schoone bladeren of lapjes blauw katoen; terwijl om het hoofd en het middel een bijzonder versiersel wordt bevestigd, vervaardigd van kunstig, eigen gemaakt, gevlochten touw, versierd met kraaltjes. Dit versiersel draagt den naam van posbu.

Haar schaamtegordel is dan ook niet van rood of blauw katoen maar van boomschors vervaardigd, de voorouderlijke dracht, die ook gedragen wordt bij doodenfeesten.

Boven schreef ik reeds dat bij het uittreden weder eene plechtigheid voltrokken wordt, het reeds genoemde dissen wark, ook wel genoemd w'or (or - roepen).

Het meisje is daar niet bij tegenwoordig; zij wordt alleen uit het huis gehaald (waarbij zij steeds gedragen wordt, opdat zij niet in aanraking kome met de vuile aarde) om, ja, ik weet het niet beter uit te drukken dan met te zeggen, om het voedsel dat op dit feest genuttigd wordt te zegenen.

Het voedsel, dat bestaat uit in bladeren gewikkeld sagopoeder, gepoft tusschen warme steenen, wordt dan op den grond gelegd, waarna het meisje haar rechtervoet er op plaatst; met haar linker staat zij op een mat. Terwijl er inmiddels flink gezongen wordt, draagt men haar na een poos naar het huis terug. Er is dan van hare kracht overgegaan in het voedsel.

En nu de vraag, waarom heet zulk een meisje dan insos?

Boven schreef ik reeds dat in - vrouw, en sos-kleur beteekent.

Door het langdurig verblijf houden in het donker, het dus niet blootgesteld worden aan het zonnelicht, wordt de huidskleur lichter, verschilt dus zulk een meisje in den beginne van kleur 
met hare andere rasgenooten; zij krijgt dus "vrouwenkleur». In de Dorehbaai waar men de beteekenis van sos, kleur niet kende (men weet zelfs precies te zeggen waar en wanneer men het eerste insosfeest vierde), leidt men de beteekenis af van soes, wat dan melk zou beteekenen. Immers heet daar slechts de oudste dochter wanneer haar eerste kind geboren is insos, wat dan zou beteekenen: "de vrouw, die melk geeft».

Een meisje, eenmaal tot insos gemaakt, wordt steeds met dien naam genoemd of geroepen. Het is op de Schouten-eilanden geen eerenaam, zooals in de Dorehbaai, wijl hier elk meisje in sos wordt.

$\mathrm{K}$ 'bor is het feest voor de jongelingen, zooals insos het is voor de meisjes.

Alleen met dit verschil dat na het insosfeest de meisjes tot de getrnuwde vrouwen behooren en de jongens na het k'bor niet altijd tot de getrouwde mannen, hoewel een jongeling om te trouwen eerst tot k'bor verheven moet zijn.

Maar laat ik alvorens verder te gaan, ook hier eerst het woord ontleden.

Het bestaat ook uit twee deelen, en wel uit: kuk en bori. $\mathrm{Kuk}$ is steken en bori is het bovenste deel van iets, in dit geval van den penis. De bevolking spreekt echter nooit het woord uit kukbori, maar laat " $\mathrm{uk}$ » uitvallen en neemt daarvoor in de plaats een klank die het midden houdt tusschen een $a$ en $e$. Wil men het juist schrijven zooals de bevolking het uitspreekt, dan moet het geschreven worden op de wijze waarop het boven dit opstel staat, dus k'bor. De i aan het einde van het woord wordt mede niet uitgesproken.

Evenals het meisje wordt de jongen ook opgesloten, doch niet in een kamertje afgezonderd van de anderen, maar boven in het huis. Op andere plaatsen wordt er in den middengang van het huis een kamertje gemaakt van matten, waarin de jongen verblijf houdt, echter niet zoo lang als het meisje. Hem wordt ook voedsel verschaft, doch juist zooveel, dat hij niet den hongerdood behoeft te sterven, doch ook weer zoo weinig dat hij nooit genoeg heeft. Het gevolg is dan ook dat het jongemensch een ieder die hem poogt te naderen met andere bedoelingen dan hem voedsel te geven, met kleine pijltjes beschiet. Vaak richt hij daardoor ongelukken aan, bijv. dat hij 
den een of ander in het oog schiet, zulk een oog is dan ook verloren. Op Bosnik wees men mij een man die op zulk een wijze het gebruik van zijn rechteroog had verloren.

De beteekenis van dit feest is om den jongen tot $\mathrm{mambri}$ d. i. held te maken.

Is de opsluiting van het meisje van betrekkelijk langen duur, de jongen zit hoogstens 10 dagen in het bovenste deel van het huis of in het geïmproviseerde kamertje. Na afloop van deze tien dagen, wordt hij verlost uit zijn gedwongen gevangenschap, komt naar beneden en wordt door de mannen medegenomen naar het bosch, waar hij door hen gevoed wordt met een blad, dat in den volksmond den naam draagt van undaim m a m bri d. i. heldenblad.

$\mathrm{Nu}$ wordt een aanvang gemaakt met het feest waarop de handeling $\mathrm{kukbori}$ verricht zal worden. Mannen en jongens vermaken zich op het strand en nu moet de jongeling zijn vaardigheid vertoonen in het slaven-maken. Hij sluipt daartoe op listige manier uit het bosch en tracht de spelenden te overrompelen en een van hen gevangen te nemen. Hoe meer hij er gevangen neemt, des te succesvoller roof- of zgn. raaktochten wachten hem in zijn verder leven.

$\mathrm{Na}$ een wijle gaat men over tot de eigenlijke handeling, welke op de volgende wijze geschiedt. Men neemt een scherp gepunte bamboe of mes en steekt (kuk) daarmede in de bovenvlakte van den penis. De steken raken alleen de scheede van den penis; het preputium, de glans en het geheele sponsachtig lichaam worden niet geraakt, en blijven dus onbeschadigd.

Het bloed dat bij deze bewerking te voorschijn komt, wordt opgevangen in een klapperdop. Door de oudere en jonge zusters van den jongen wordt dit bloed verwerkt in sagokoeken, die door hen genuttigd worden. Waarom dit geschiedt kon ik van de bevolking niet te weten komen; Dr. Alb. C. Kruyt, tot wien ik mij wendde om inlichtingen en verklaring, schreef mij: "wanneer ik u wel begrepen heb, is het k'bor-feest het laatste feest, dat gegeven wordt voor den jongeling; m. a. w.: daarna is hij man, dat wil zeggen, moet hij trouwen en is hij verplicht mede alles te doen om den stam in stand te houden, in de eerste plaats door kinderen te verwekken. Wanneer deze vooropzetting juist is, is het gebruik dat gij noemt, om de zusters bloed te laten eten afkomstig van den penis van haar broeder, 
duidelijk. Naar mijn gedachte heeft dit gebruik de bedoeling om bloedschande, copulatie van den jongeling met zijne zusters, te voorkomen.»

Wanneer ik nu daarbij voeg dat op Biak bloedschande zeer zwaar gestraft wordt, met groote boeten, dan dunkt het mij dat voor deze verklaring van den Heer Kruyt zeer veel pleit.

Op een ander deel van Biak wordt dit bloed niet door de zusters genuttigd maar met palmwijn vermengd, door de groote mannen opgedronken. Voor deze wijze van handelen gaf men echter wel een verklaring en wel de volgende: dat door deze handeling de mannen de verplichting op zich namen den jongeling door dik en dun met alles te helpen. Krijgt hij moeite, de anderen zullen hem helpen. Vermoedelijk ligt dan ook in dit feest de oorsprong van het feit dat indien door bestuursambtenaren of soldaten gezocht wordt naar een Papoea die al te veel op zijn kerfstok heeft, de geheele kampong het bosch in vlucht en er niet toe te bewegen is den gezochte uit te leveren, en indien zij niet mede het bosch zijn in gevlucht, op alle vragen met een ontkenning antwoorden. Alleen wanneer men zelf overlast heeft van den persoon in kwestie, zal men *de compagnie» behulpzaam zijn. Men zou dus dit k'bor-feest kunnen noemen een feest om een jongeling toe te laten tot een soort van "mannenverbond».

Echter wil ik mij ook aan een andere verklaring wagen. Aan de zusters wordt het bloed gekomen uit den penis van den jongeling te eten gegeven; zou men hierdoor niet te kennen willen geven (gegeven het feit dat op Biak het matriarchaat bestaat) dat elke vrucht voortgebracht door den jongeling den vrouwen behoort, dat zij daar recht op hebben?

$\mathrm{Na}$ dit feest wordt zulk een jongeling altijd genoemd en geroepen met den naam k'bor. Echter is er één uitzondering; wanneer de jongeling, tijdens de behandeling blijken van pijn geeft door schreeuwen of anderszins, behoudt hij zijn jongensnaam en wordt nooit k'bor genoemd.

Waarom worden echter de jongens aan deze pijnlijke behandeling onderworpen en zijn zij er trotsch op k'bor te heeten?

Het is een vasthouden aan de adat, want wordt het niet gedaan, dan vreest de Papoea de geesten der voorouders. Dezen zouden dan boos worden, omdat niet is vastgehouden aan de 
voorouderlijke adat. Besluit een Papoea te breken met deze adat, dan laat hij een groot stuk van zijn vrees voor geesten vallen.

De zending komt met den eisch: geen k'bor-feesten meer, wanneer gij Kristen wordt of wanneer gij een goeroe begeert. Wordt hieraan voldaan, dan is het een bewijs dat het der bevolking ernst is met haar vraag om een goeroe en met haar wensch Kristen te worden. Ditzelfde geldt mede voor het in sosfeest.

Het geheele feest dat gehouden wordt voor een jongeling die tot k'bor gemaakt wordt, wordt ook wel genoemd jerensram.

Dit woord is samengesteld uit: ja, eren en sram.

$\mathrm{Ja}$ is het pers. voornw. $1^{\text {ste }}$ pers. enkelv.; e re $\mathrm{n}$ is het noefoorsche woord voor nachtenbinden (de Papoea rekent met nachten en niet met dagen; spreekt men bijv. met hem af dan en dan te vertrekken dan zegt men: rob di rim kaker ko bur d. i. vijf nachten nog dan vertrekken wij. Hij onthoudt dan dat aantal door in een touwtje vijf knoopen te leggen of te binden-ko fes rob-nachten binden. Na elke nacht die voorbij gegaan is, ontwart hij één knoop; en wanneer alle knoopen ontward zijn, dan is hij op zijn post.

Sram. Wat dit woord beteekent weet men nog niet goed. Men leidt het af van dalam - wat het binnenste van iets beteekent, het inwendige. Het geheele woord jerensram zou dan aldus omschreven kunnen worden: ik bind nachten voor dengene die in het binnenste verblijf hield.

Het insos-feest en het k'bo, r-feest zijn de laatste feesten welke voor een heidenschen papoeschen jongeling of meisje worden gehouden, doch ook de grootste.

Mandoesir. (Biak, Schouten-eilanden). 